\title{
BEBERAPA ASPEK REPRODUKSI IKAN LAYANG (Decapterus russelli) DAN IKAN BANYAR (Rastrelliger kanagurta) DI PERAIRAN SELAT MALAKA INDONESIA
}

\author{
Tuti Hariati"), Muhammad Taufik", dan Achmad Zamroni")
}

\begin{abstract}
ABSTRAK
Penelitian reproduksi ikan layang (Decapterus russelli) dan ikan banyar (Rastrelliger kanagurta) dari Selat Malaka Indonesia dimaksudkan untuk memperoleh dugaan lokasi dan musim pemijahan serta panjang pertama kali matang gonad $\left(\mathrm{I}_{\mathrm{m}}\right)$. Hasil penelitian diharapkan dapat digunakan sebagai dasar pengelolaan stok kedua jenis ikan tersebut. Contoh ikan layang dan banyar dari yang berukuran sedang sampai besar $(14 \mathrm{~cm}-$ $22 \mathrm{~cm}$ untuk ikan layang dan $17 \mathrm{~cm}-23 \mathrm{~cm}$ untuk ikan banyar) dikumpulkan tiap bulan selama periode bulan Mei 2003 sampai dengan bulan Desember 2004 dari hasil tangkapan pukat cincin yang didaratkan di Tanjung Balai, Propinsi Sumatera Utara masing-masing 1.000 ekor. Pengamatan tiap bulan dilakukan terhadap panjang dan berat tubuh, jenis kelamin, serta tingkat kematangan gonad dan berat gonad dari ikan betina, untuk menghitung nilai persentase ikan yang matang gonad dan indeks gonad spesimen tiap bulan serta panjang rata-rata pertama kali matang gonad $\left(I_{m}\right)$. Hasil penelitian menunjukkan bahwa musim pemijahan untuk ikan layang berlangsung dari bulan April sampai dengan Oktober, sedangkan untuk ikan banyar berlangsung dari bulan Mei sampai dengan bulan Oktober dan bulan Desember sampai dengan bulan Maret. Lokasi pemijahan kedua spesies tersebut diduga terletak di bagian utara Selat Malaka sekitar garis isodepth 200 meter. Nilai-nilai ikan layang dan banyar masing-masing $16 \mathrm{~cm}$ FL dan $17 \mathrm{~cm}$ FL.
\end{abstract}

\begin{abstract}
Some aspects of reproduction of round scad (Decapterus russelli) and Indian mackerel (Rastrelliger kanagurta) in the Straits of Malacca, part of Indonesia. By: Tuti Hariati, Muhammad Taufik, dan Achmad Zamroni

A research on reproduction of round scad (Decapterus russelli) and Indian mackerel (Rastrelliger kanagurta) from the Straits of Malacca, part of Indonesia aims to estimate the spawning season and area, and the length at first maturity $\left(I_{\mathrm{m}}\right)$ of both Scad and Indian mackerel stock. The result was expected to be used as a basic for management of the stock. The samples of round scad and mackerel of medium to big size $(15 \mathrm{~cm}$ and more) 1,000 fish for each species were collected by month during the period of May 2003-December 2004 from the catch of purse seine fleet landed in Tanjung Balai, North Sumatera Province. The monthly observations were emphasized on body length and weight measurement, maturity, and weight of gonad of the female, in order to get the values of percentage of maturity and gonad index as well as $I_{m}$ values. The results show that spawning season for the round scad occurred from April to October, while the mackerel occurred from May to October and from December to March. Spawning area of both species was estimated in the northern part of the Malacca Straits, around 200 meters Isodepth line. The values of $L_{m}$ of round scad and Indian mackerel are $16 \mathrm{~cm} F L$ and $17 \mathrm{~cm}$ FL, respectively.
\end{abstract}

KEYWORDS: $\quad$ reproduction, round scad, Indian mackerel, Malaka Strait

\section{PENDAHULUAN}

Perairan Selat Malaka yang subur memiliki bermacam-macam sumber daya ikan laut di antaranya jenis-jenis udang, ikan demersal dan ikan pelagis. Jenis-jenis ikan layang (Decapterus spp.) dan kembung (Rastrelliger spp.) merupakan sumber daya ikan pelagis yang penting sebagai sumber protein hewani maupun sebagai komoditas ekspor, seperti ikan banyar ( $R$. kanagurta) dan ikan kembung $(R$. brachyosoma) untuk negara Singapura.

Di perairan Selat Malaka, ikan pelagis kecil hanya tertangkap di setengah bagian utara yang berhubungan langsung dengan Samudera Hindia. Pada setengah bagian selatan Selat Malaka yang berhubungan langsung dengan Laut Cina Selatan ikan pelagis kecil hampir tidak pernah tertangkap.
Kadar garam di setengah bagian utara di atas 30\%, sedangkan di bagian selatan di bawah $30 \%$ o (Nurhayati, 2002). Ujung bagian selatan Selat Malaka merupakan pintu masuk air laut dari Laut Cina Selatan dengan kadar garam yang rendah, selain juga pada musim hujan masuk air tawar dari daratan Riau melalui sungai-sungai (Nurhayati, 2002).

Di perairan Selat Malaka wilayah Malaysia, ikan pelagis kecil ditangkap oleh para nelayan dari negaranegara bagian Perlis, Kedah, Penang, Perak, dan Selangor, namun dilepas pantai Negeri Sembilan, Malaka, dan Johor, ikan pelagis kecil hampir tidak tertangkap (Chee Phaik Ean, 2000). Di Selat Malaka wilayah Indonesia, ikan pelagis kecil tertangkap di propinsi-propinsi Nangroe Aceh Darussalam dan Sumatera Utara, sedang di Propinsi Riau hampir tidak tertangkap.

\footnotetext{
Peneliti pada Balai Riset Perikanan Laut, Jakarta
} 
Pada umumnya jenis-jenis ikan pelagis kecil hidup di perairan dengan kadar garam di atas $30 \%$. Jenisjenis ikan pelagis di perairan Selat Malaka bagian utara ada yang hidup di perairan kostal seperti ikan kembung ( $R$. brachyosoma), japuh (Dussumieria acuta), dan di perairan neritik seperti ikan layang $(D$. russelli), dan oseanik (D. macarellus). Ada juga yang euryhaline seperti ikan tembang (Sardinella spp.). Ikan banyar (Rastrelliger kanagurta) dan ikan layang (Decapterus russelli) hidup di perairan dengan kadar garam tidak kurang dari $32 \%$. Ikan banyar bersifat neritik oseanik tertangkap baik di laut dalam misalnya di perairan Banda Aceh, maupun di atas paparan seperti di perairan wilayah Aceh Timur dan Sumatera Utara. Adapun ikan layang, hanya tertangkap di atas paparan (neritik). Kedua spesies tersebut mendominasi hasil tangkapan pukat cincin pada musim barat (Desember-Februari) di perairan Aceh Timur, juga pada musim Timur (Juni sampai dengan Agustus) sampai musim Peralihan II (September sampai dengan Nopember) di perairan timur Sumatera Utara. Jenis-jenis ikan kembung (Rastrelliger kanagurta dan $R$. brachyosoma) yang terdapat di perairan Selat Malaka merupakan 1 unit stok (Tampubolon \& Merta, 1986).

Penelitian aspek reproduksi ikan banyar dan ikan layang di perairan Selat Malaka wilayah Indonesia, pada tahun 2003 sampai dengan tahun 2004 dimaksudkan untuk memperoleh informasi mengenai pemijahan mencakup musim dan ukuran pertama kali matang gonad $\left(I_{m}\right)$ kedua spesies tersebut, yang dapat digunakan sebagai dasar kebijakan pengelolaan stok.

\section{BAHAN DAN METODE}

Penelitian dilakukan di wilayah Tanjung Balai yang merupakan salah satu pusat pendaratan kapal pukat cincin Selat Malaka yang cukup strategis dan aman untuk situasi saat ini. Pengambilan contoh ikan layang pipih (Decapterus russelli) dan ikan banyar (Rastrelliger kanagurta) dari kapal-kapal sampel dilakukan selama 20 bulan, dari bulan Mei 2003 sampai dengan bulan Desember 2004.

Pada tiap bulan, 50 contoh ikan layang ukuran 14$22 \mathrm{~cm}$ dan 50 contoh ikan banyar ukuran 17-23 cm (yang jenis kelaminnya sudah dapat ditentukan) diukur panjang cagak ( $F L)$, panjang total ( $T L)$, dan berat tubuh (W), diamati jenis kelaminnya serta ditimbang berat gonadnya $(\mathrm{Wg})$. Ikan betina diamati lebih jauh tingkat kematangan gonad atau ovarium (TKG) secara visual sesuai dengan kriteria tingkat kematangan gonad berikut (Holden \& Raitt, 1974):

1. Tahap awal: Ovarium seperti benang, permukaan licin.

2. Tahap berkembang: Ovarium lebih besar, telur belum terlihat dengan mata.
3. Mulai matang: Gonad berwarna kuning, tampak butiran telur dan salıran darah

4. Matang: Ovarium makin besar, bentuknya bening seperti agar, mengisi $1 / 2,2 / 3$, sampai mencapai ukuran maksimum (fully developed gonad) yang siap memijah.

5. Memijah sampai spent: ovarium berkerut karena tclur berangsur-angsur dilepaskan, sampai setengah dari ruang badan. Ovarium berisi sisa pelepasan butir-butir telur yang opaque dan yang matang.

Pada bulan Juli 2004 diambil beberapa contoh gonad ikan banyar yang matang (TKG IV), kemudian diawetkan dengan larutan Gilson untuk memperoleh contoh telur, terutama yang translucent.

\section{Analisis}

Pada tiap bulan jumlah contoh ikan jantan dan betina dihitung. Setelah 20 bulan, dicari perbandingan jumlah ikan jantan dan betina dari tiap spesies dengan uji Khi kwadrat. Musim pemijahan diduga dari puncak persentase ikan TKG IV (matang) dan terdapatnya ikan TKG V (spent).

Nilai Gonad Indeks tiap individu betina dihitung dengan rumus:

$\mathrm{Gl}=\mathrm{Wg} / \mathrm{L}^{3} \cdot 10^{5}$ (Schaefer \& Orange in Batts, 1972,)

di mana:

$$
\begin{aligned}
\mathrm{Gl} & =\text { Gonad Indeks } \\
\mathrm{Wg} & =\text { berat gonad } \\
\mathrm{L} & =\text { panjang ikan }(\mathrm{cm} \mathrm{FL})
\end{aligned}
$$

Dari grafik sebaran GI maksimum, GI minimum, dan GI rata-rata tiap bulan dapat diduga musim pemijahan, yaitu adanya penurunan nilai GI (max min, dan rata-rata).

Panjang ikan pertama kali matang gonad $\left(I_{m}\right)$ diduga menurut metode Spearman-Karber (Udupa 1986): $m=X^{k}+X / 2-\left(X^{*} \sum p_{i}\right)$, selanjutnya $I_{m}=\operatorname{antilog}(m)$,

di mana:

$$
\begin{aligned}
X_{k}= & \text { log nilai tengah yang terakhir di mana ikan } \\
& \text { telah matang (TKG IV) } \\
X \quad & \text { selisih log nilai tengah } \\
P \quad= & \text { perbandingan antara jumlah ikan yang } \\
& \text { matang gonad pada kelompok panjang ke-i } \\
\text { Ant }= & \text { antilog }
\end{aligned}
$$

Batas kepercayaan $95 \%$ dihitung dengan rumus: ant. $\left(m+-1,96 \vee\left(X^{2} \cdot \Sigma_{i}\left(\left(p_{i} \cdot q_{i}\right) /\left(n_{i}-1\right)\right)\right.\right.$,

di mana:

$$
\begin{aligned}
& q_{i}=1-p_{i} \\
& n_{i}=\text { jumlah contoh ke-i }
\end{aligned}
$$




\section{HASIL DAN BAHASAN}

\section{Ratio Jenis Kelamin}

Selama 20 bulan pengamatan diperoleh contoh ikan layang (Decapterus russelli) betina 517 ekor $(51,7 \%)$ sedangkan jenis jantan 483 ekor $(48,3 \%)$, sehingga perbandingan jenis kelamin betina:jantan dari contoh ikan layang adalah 1,00:0,93. Pada periode yang sama diperoleh 461 ekor contoh ikan banyar (Rastrelliger kanagurta) betina (46\%) dan 539 ekor jenis jantan (54\%), atau dengan perbandingan betina:jantan 1,00:1,17. Dengan uji Khi kwadrat diketahui bahwa untuk contoh ikan layang perbandingan jenis betina dan jantan masih seimbang atau setara dengan 1:1 (agregasi), sedangkan untuk ikan banyar perbandingan jenis betina dan jantan tidak seimbang, jumlan jantan lebih banyak (segregasi). Menurut Bal \& Rao (1984), segregasi atau agregasi jantan dan betina ada hubungannya dengan tabiat makan, memijah atau migrasi dari tiap jenis ikan.

\section{Tingkat́ Kematangan Gonad dan Panjang Pertama Kali Matang Gonad}

Tingkat Kematangan Gonad (TKG)

\section{Decapterus russelli}

Dari Gambar 1, contoh ikan layang betina selama periode pengamatan didominasi ikan yang matang gonad $(57 \%)$, yang terdiri atas TKG III dan IV. Ikan yang belum matang (TKG I dan II) hanya $41 \%$ sedangkan $2 \%$ lainnya terdiri atas ikan yang sedang memijah dan yang selesai memijah (TKG V). Kondisi tingkat kematangan gonad ikan layang yang tertangkap di perairan Selat Malaka agak berbeda dengan yang tertangkap di Laut Jawa dan Laut Cina Selatan, yang pada umumnya terdiri atas ikan yang belum matang gonad. Hal ini, diduga karena daerah penangkapan pukat cincin Tanjung Balai di perairan Selat Malaka saat ini (perairan Aceh Timur sampai Ujung Jambo Ayer) lebih dekat dengan daerah pemijahan ikan layang.

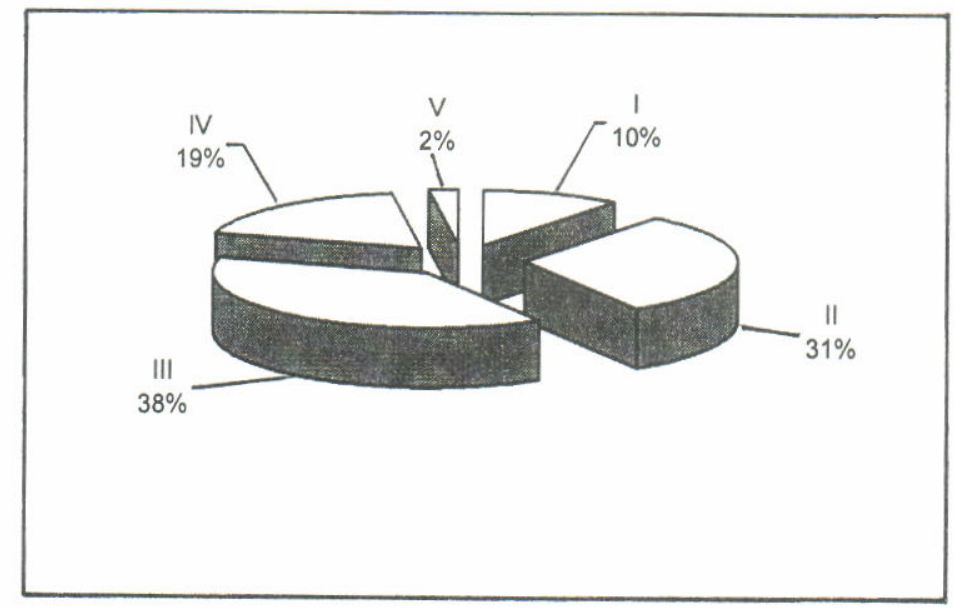

Gambar 1. Komposisi tingkat kematangan gonad ikan layang (Decapterus russelli) betina di perairan Selat Malaka tahun 2003-2004.

Figure 1. Maturity composition of female scad (Decapterus russelli) from Malaka Strait waters in 20032004.

Dari Tabel 1 dapat dilihat bahwa contoh ikan TKG I selama pengamatan tidak terdapat setiap bulan. Jika ada, dalam persentase yang rendah, kecuali pada bulan Agustus, Oktober, dan Desember 2004. TKG II ditemukan setiap bulan, dengan persentase tinggi terjadi pada bulan Mei 2003 dan Januari, April, Nopember, dan Desember 2004. Tingginya persentase TKG II pada bulan Nopember dan Desember 2004 (Tabel 1) diduga karena ikan sampel yang diperoleh pada bulan tersebut berasal dari daerah penangkapan yang lebih dekat pantai.

Berat gonad terkecil 0,05 gram (TKG I) dimiliki individu yang berukuran $15 \mathrm{~cm} F L$, yang terbesar 6,3 gram pada inciividu yang berukuran $19,9 \mathrm{~cm}$ FL (TKG IV). Individu dengan panjang lebih dari $19,9 \mathrm{~cm}$ mempunyai berat gonad 0,9 sampai dengan 5,6 gram yang umumnya terdiri dari TKG V dan IV. Pada penelitian tahun 1993 diperoleh ikan betina dengan berat gonad 10 gram, diduga gonad terbesar yang ditemukan pada tahun 2003-2004 masih belum berkembang sampai berat maksimal (fully development gonad).

TKG III ditemukan setiap bulan dengan persentase yang tinggi pada bulan Juli sampai dengan Nopember 2003, bulan Mei sampai dengan Juli dan September 2004 (Tabel 1), yang akan berkembang menjadi lebih matang (TKG IV). Dalam Tabel 1 juga terlihat bahwa betina ikan layang TKG IV ditemukan tiap bulan, kecuali pada bulan Oktober 2003 dan Agustus 2004, Oktober sampai Desember 2004. TKG V tidak 
Tabel 1. Komposisi Tingkat Kematangan Gonad (TKG) ikan layang (Decapterus russelli) setiap bulan di perairan Selat Malaka

Table 1. Monthly composition of maturity stage of round scad (Decapterus russelli) in the Straits of Malacca

\begin{tabular}{lccccc}
\hline \multirow{2}{*}{ Bulan/Month } & \multicolumn{5}{c}{$\begin{array}{c}\text { Komposisi ingkat kematangan gonad ikan layang } \\
\text { (Composition of maturity stage (\%) of female round scad) }\end{array}$} \\
\cline { 2 - 6 } & I & II & II & IV & V \\
\hline 2003 & & & 11,1 & 13,9 & 0,0 \\
Mei & 8,3 & 66,7 & 30,4 & 47,8 & 13,0 \\
Juni & 0,0 & 8,7 & 61,3 & 25,8 & 0,0 \\
Juli & 0,0 & 19,4 & 48,4 & 19,4 & 6,5 \\
Agustus & 0,0 & 25,8 & 60,0 & 32,0 & 0,0 \\
September & 0,0 & 8,0 & 76,0 & 0,0 & 12,0 \\
Oktober & 12,0 & 24,0 & 44,4 & 18,5 & 3,7 \\
Nopember & 3,7 & 29,6 & 63,3 & 20,0 & 0,0 \\
Desember & 0,0 & 16,7 & & & \\
2004 & & & 35,5 & 12,9 & 0,0 \\
Januari & 3,2 & 48,4 & 25,0 & 39,3 & 0,0 \\
Pebruari & 7,1 & 28,6 & 28,0 & 32,0 & 0,0 \\
Maret & 8,0 & 32,0 & 20,0 & 5,0 & 10,0 \\
April & 10,0 & 55,0 & 41,2 & 35,3 & 0,0 \\
Mei & 0,0 & 23,5 & 50,0 & 14,3 & 0,0 \\
Juni & 3,6 & 32,1 & 71,4 & 9,5 & 0,0 \\
Juli & 9,5 & 9,5 & 5,3 & 0,0 & 0,0 \\
Agustus & 84,2 & 10,5 & 37,5 & 43,8 & 0,0 \\
September & 0,0 & 18,8 & 4,0 & 0,0 & 0,0 \\
Oktober & 60,0 & 36,0 & 27,3 & 0,0 & 0,0 \\
Nopember & 4,5 & 68,2 & 21,7 & 0,0 & 0,0 \\
Desember & 26,1 & 52,2 & &
\end{tabular}

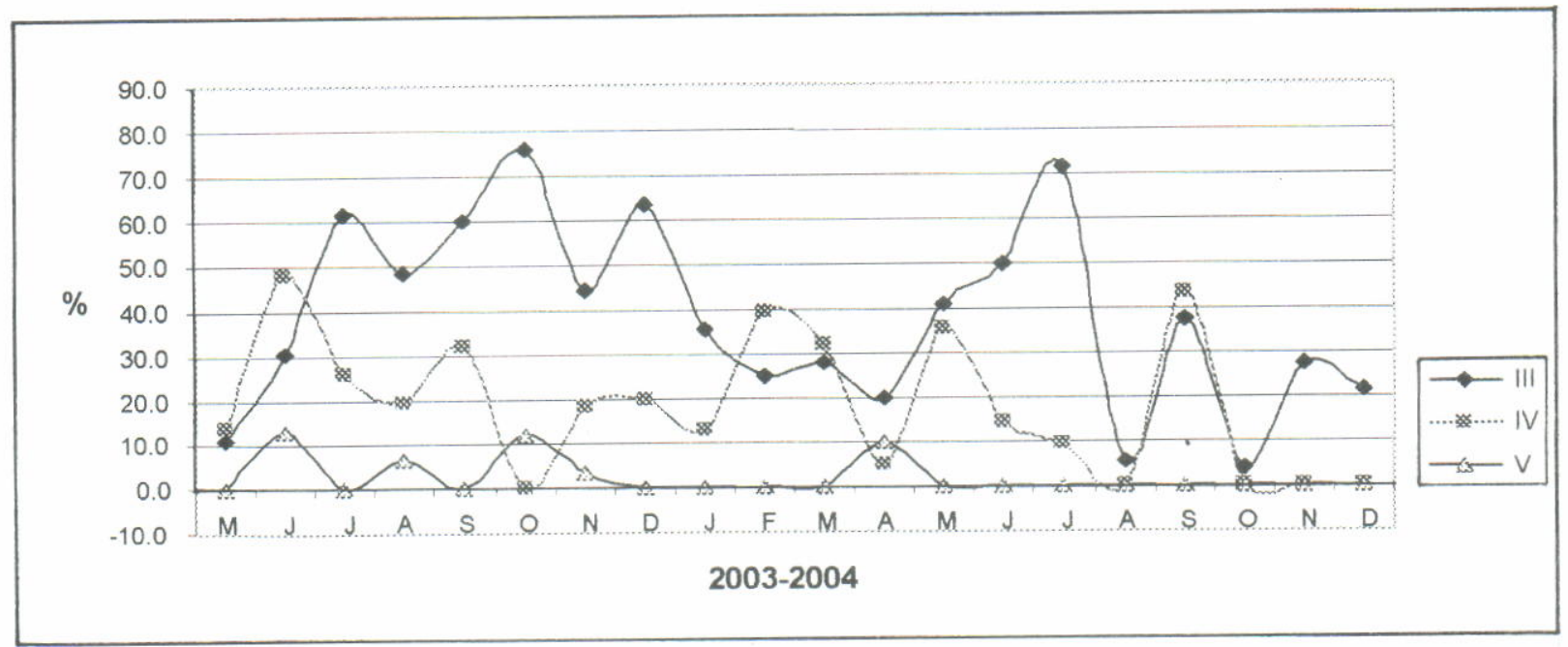

Gambar 2. Fluktuasi Tingkat Kematangan Gonad III, IV, dan V ikan layang (Decapterus russelli) betina dari perairan Selat Malaka.

Figure 2. Fluctuation of maturity stage III, IV, and $V$ of female scad (Decapterus russelli) from the Malacca Straits.

ditemukan setiap bulan kecuali pada bulan Juni, Agustus, Oktober, Nopember 2003, dan bulan April 2004. Keberadaan ikan betina TKG V pada bulan Juni 2003 merupakan indikasi pada bulan April-Mei 2003 terjadi pemijahan.
Pada bulan Juni 2003 persentase TKG IV (matang) meningkat, lalu pada bulan Juli sampai dengan Agustus 2003 turun, disusul dengan terdapatnya ikan betina TKG V (memijah dan selesai memijah atau spent) pada bulan Agustus dan Oktober 
2003. Dari bulan Nopember sampai dengan bulan Maret 2003 persentase TKG IV cenderung naik kemudian pada bulan April 2004 turun disertai munculnya ikan betina TKG V (Gambar 1).

Persentase ikan layang betina TKG IV bulan Mei 2004 turun pada bulan Juni sampai dengan Agustus 2004, diduga pada periode bulan Juni sampai dengan bulan Agustus 2004 terjadi pemijahan. Pada bulan September 2004 TKG IV naik, kemudian turun pada bulan Oktober sampai dengan bulan Desember 2004. Turunnya persentase TKG IV pada bulan Oktober 2004 diduga karena betina yang telah matang bermigrasi untuk melangsungkan pemijahan. Maka diduga bahwa pemijahan ikan layang pada tahun 2003 dan 2004 terjadi pada bulan April sampai dengan bulan Oktober dengan puncak musim pada bulan April dan bulanOktober.

\section{Rastrelliger kanagurta}

Dari 461 ekor contoh ikan banyar betina, $64 \%$ terdiri dari ikan yang mulai matang dan yang matang gonad (TKG III dan TKG IV), ikan betina yang belum matang gonad (TKG I dan TKG II) jumlahnya 26\%, sedangkan sisanya (TKG V) hanya 10\% (Gambar 3). Dengan demikian contoh ikan banyar betina juga didominasi oleh ikan yang mulai matang dan yang matang gonad.

Berat gonad terkecil $0,3 \mathrm{~g}$ (TKG I) dimiliki individu yang berukuran $17,7 \mathrm{~cm}$ FL, yang terbesar 8,8 gram pada individu yang berukuran 21,1 cm FL (TKG IV). Rao (1967) mencatat berat gonad yang maksimal ditemukannya adalah $16,8 \mathrm{~g}$ dari ikan dengan panjang tubuh $23,8 \mathrm{~cm}$, tertangkap dengan sejenis gillnet dasar di perairan India.

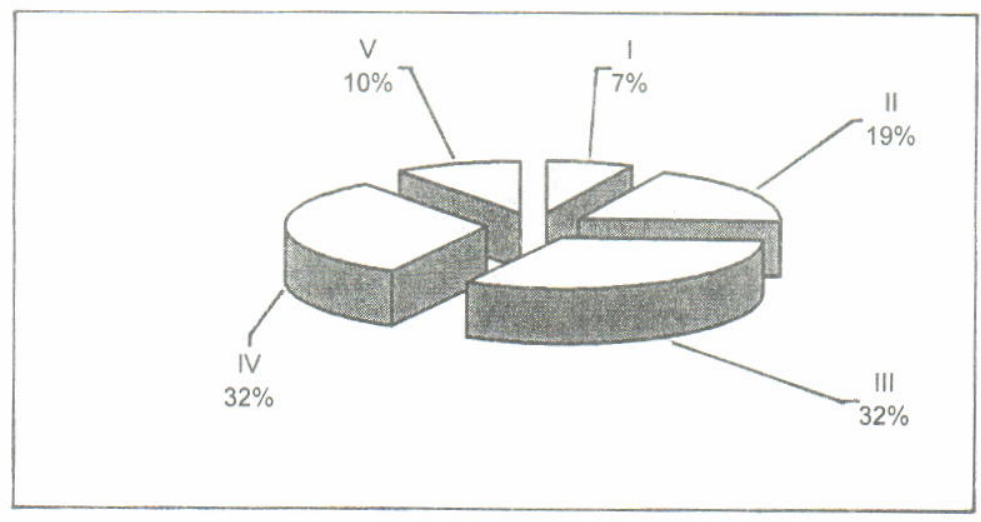

Gambar 3. Tingkat Kematangan Gonad ikan banyar (Rastrelliger kanagurata) betina dari perairan Selat Malaka tahun 2003-2004.

Figure 3. Maturity composition of female Indian mackerel (Rastrelliger kanagurata) from Malacca Strait's waters in 2003-2004.

Dari Tabel 2 terlihat bahwa ikan banyar betina TKG I tiap bulannya sangat jarang terdapat, kalaupun ada dalam jumlah yang kecil, kecuali pada bulan Oktober 2003 dan bulan Desember 2004 masingmasing $40 \%$ dan $50 \%$. TKG II terdapat hampir pada tiap bulan, dengan persentase tinggi pada bulan Oktober 2003, Januari, Oktober, sampai dengan Desember 2004. TKG III (gonad mulai matang) dan TKG IV (gonad matang) terdapat tiap bulan, sedangkan TKG $V$ ditemukan pada bulan Nopember 2003, Maret dan Juni 2004, juga pada bulan Juli dan Agustus 2004 dalam persentase yang sangat tinggi.

Dari Gambar 4 terlihat bahwa persentase yang tinggi dari ikan banyar betina TKG III terjadi terutama pada bulan Mei, September, dan Desember 2003, serta pada bulan Januari, Maret, Mei, Juni, dan Oktober 2004. TKG IV mencapai puncak pada bulan Agustus sampai dengan September dan Nopember sampai dengan Desember 2003, kemudian pada bulan-bulan Pebruari, April, Juni, dan September 2004. Persentase ikan banyar betina TKG IV turun dari bulan-bulan sebelumnya pada bulan Juni dan Oktober 2003, serta pada bulan-bulan Januari, Maret, Juli sampai dengan Agustus, Oktober yang berlanjut hingga Nopember sampai dengan Desember 2004. Turunnya persentase TKG IV diduga merupakan indikasi terjadinya pemijahan.

Ikan betina TKG $V$ yang tertangkap pada bulan Nopember 2003 dan Maret 2004 diduga adalah yang telah melakukan pemijahan pada bulan Oktober 2003, bulan Januari dan Maret 2004. Ikan betina TKG $V$ yang tertangkap pada bulan Juni serta Juli sampai dengan Agustus 2004 (puncak) diduga yang melakukan pemijahan pada bulan Mei, Juli, dan Agustus 2004, sedangkan yang tertangkap pada bulan Nopember 2004 diduga yang melakukan pemijahan pada bulan Oktober 2004 dan atau Nopember 2004.

Berdasarkan pada fluktuasi persentase ikan banyar betina TKG III sampai dengan TKG V dari bulan Mei 2003 sampai dengan Desember 2004 
Tabel 2. Komposisi Tingkat Kematangan Gonad (TKG) ikan banyar (Rastrelliger kanagurta) setiap bulan di perairan Selat Malaka

Table 2. Monthly composition of maturity stage of indian mackerel (Rastrelliger kanagurta) in the Straits of Malacca

\begin{tabular}{|c|c|c|c|c|c|}
\hline \multirow[t]{2}{*}{ Bulan/Month } & \multicolumn{5}{|c|}{$\begin{array}{l}\text { Komposisi tingkat kematangan gonad ikan banyar } \\
\text { (Composition of maturity stage (\%) of female round scad) }\end{array}$} \\
\hline & 1 & II & III & IV & V \\
\hline \multicolumn{6}{|l|}{2003} \\
\hline Mei & 0,0 & 7,7 & 69,2 & 23,1 & 0.0 \\
\hline Juni & 0,0 & 18,2 & 77,3 & 4,5 & 0.0 \\
\hline Juli & 3,4 & 27,6 & 48,3 & 20,7 & 0.0 \\
\hline Agustus & 0,0 & 3,4 & 48,3 & 48,3 & 0.0 \\
\hline September & 0,0 & 16,0 & 52,0 & 32,0 & 0.0 \\
\hline Oktober & 40,9 & 45,5 & 13,6 & 0,0 & 0.0 \\
\hline Nopember & 4,2 & 12,5 & 33,3 & 45,8 & 4.2 \\
\hline Desember & 0,0 & 6,9 & 58,6 & 34,5 & 0.0 \\
\hline \multicolumn{6}{|l|}{2004} \\
\hline Januari & 12,0 & 40,0 & 48,0 & 0,0 & 0.0 \\
\hline Pebruari & 0,0 & 0,0 & 23,1 & 76,9 & 0.0 \\
\hline Maret & 0,0 & 19,2 & 50,0 & 23,1 & 7.7 \\
\hline April & 0,0 & 0,0 & 7,7 & 92,3 & 0.0 \\
\hline Mei & 0,0 & 9,5 & 23,8 & 66,7 & 0.0 \\
\hline Juni & 0,0 & 0,0 & 20,0 & 75,0 & 5.0 \\
\hline Juli & 0,0 & 0,0 & 10,5 & 5,3 & 84.2 \\
\hline Agustus & 0,0 & 5,0 & 0,0 & 5,0 & 90.0 \\
\hline September & 0,0 & 0,0 & 9,1 & 90,0 & 0.0 \\
\hline Oktober & 8,0 & 56,0 & 36,0 & 0,0 & 0.0 \\
\hline Nopember & 8,7 & 69,6 & 13,0 & 0,0 & 8.7 \\
\hline Desember & 50,0 & 42,3 & 3,8 & 0,0 & 3.8 \\
\hline
\end{tabular}

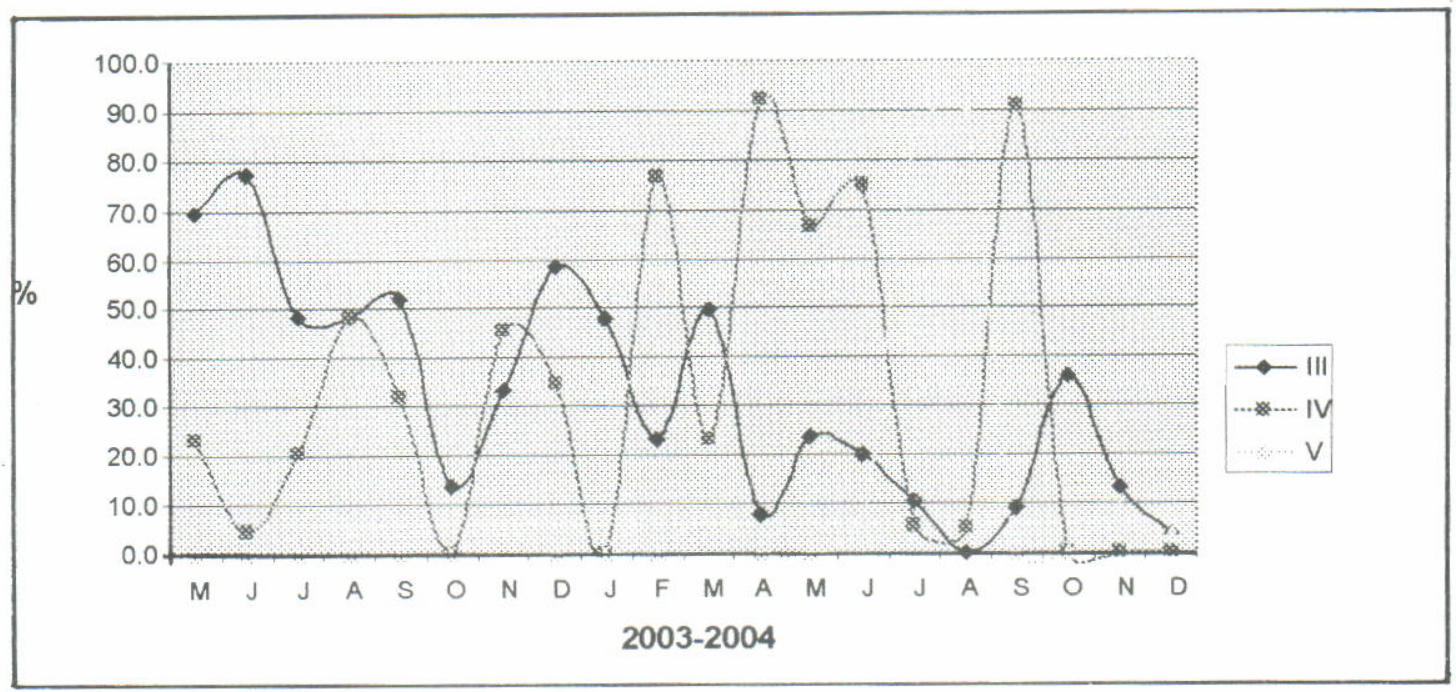

Gambar 4. Fluktuasi Tingkat Kematangan Gonag III, IV, dan V Rastrelliger kanagurata betina dari perairan Selat Malaka.

Figure 4. Fluctuation of maturity stage III, IV, and V of female of Rastrelliger kanagurata from the Malacca Straits.

(Gambar 4) diduga bahwa pemijahan ikan banyar di perairan Selat Malaka terjadi dari bulan Mei sampai dengan Oktober (musim timur sampai musim peralihan II) dengan puncak pada bulan Juli sampai dengan Agustus dan Oktober, serta pada bulan Desember sampai dengan Maret (musim barat) dengan puncak pada bulan Januari sampai dengan Maret. 
Di Laut Jawa pemijahan ikan banyar berlangsung pada bulan Maret, Mei, dan Oktober sampai dengan Nopember (Atmadja et al., 1995) sedang di perairan Selat Malaka pantai barat Thailand berlangsung pada bulan September, Desember, Januari, dan Maret (Shuttakorn \& Saranakomkul, 1987).

\section{Panjang Pertama Kali Matang Gonad $\left(I_{m}\right)$}

Dari hasil analisis telah diperoleh nilai $I_{m}$ untuk ikan layang (Decapterus russeli) di perairan Selat Malaka (dalam cm FL) adalah $16 \mathrm{~cm}(16,1 \mathrm{~cm}-16,7$ $\mathrm{cm}$ ). Nilai $I_{m}$ untuk ikan banyar (Rastrelliger kanagurta) $17 \mathrm{~cm}(16,6 \mathrm{~cm}-17,2 \mathrm{~cm})$. Dari data penelitian tahun 1995-1997 diperoleh nilai-nilai $I_{m}$ yang sama yaitu untuk ikan layang $16 \mathrm{~cm}(15-17 \mathrm{~cm})$ dan ikan banyar adalah $17 \mathrm{~cm}(16 \mathrm{~cm}-18 \mathrm{~cm})$ (Anonimus, 1998). Dengan demikian, dari tahun 1995-1997 sampai dengan 2003-2004 tidak terjadi penurunan nilai $I_{m}$ dari ikan layang dan ikan banyar.

Di perairan dekat Natuna (Laut Cina Selatan) diperoleh nilai $I_{m}$ yang kurang lebih sama, yaitu ikan layang (dalam cm TL) adalah $17,8 \mathrm{~cm}(17-18 \mathrm{~cm})$ dan untuk ikan banyar 19,7 cm $(19,3 \mathrm{~cm}-20,2 \mathrm{~cm})$ (Hariati et al., 2004).

\section{Gonad Index (GI) Maksimum dan Rata-Rata pada Tiap Bulan}

\section{Decapterus russelli}

Dari Gambar 5 diketahui bahwa $\mathrm{GI}_{\text {maks }}$ ikan layang yang tinggi (70,0 ke atas) dijumpai pada bulan Mei sampai dengan Juli, September, dan Desember 2003, kemudian pada bulan Pebruari, Mei, dan September 2004, sehingga pemijahan ikan layang dapat terjadi seteiah bulan-bulan tersebut.

Nilai GI rata-rata yang rendah dari ikan layang terjadi pada bulan Mei, Juli, Agustus, dan Oktober
2003 juga pada bulan April, Juli, Agustus, dan Oktober. Hal ini, mendukung dugaan musim pemijahan ikan layang yang berlangsung pada bulan April sampai dengan Oktober (musim peralihan I, musim timur sampai dengan musim peraihan II), yang didasarkan perkembangan gonad ikan layang (Gambar 2). Di Laut Jawa musim pemijahan ikan layang berlangsung dari bulan Mei sampai dengan Desember (Atmadja et al., 1995), sedangkan di perairan Selat Malaka wilayah Thailand berlangsung antara bulan Desember sampai dengan Mei (Shuttakorri \& Saranakomkul, 1987).

\section{Rastrelliger kanagurta}

Pada tahun 2003 nilai $\mathrm{GI}_{\text {maks }}$ yang tinggi ditemukan pada bulan Mei, Agustus, September, dan Nopember, sedangkan pada tahun 2004 ditemukan nilai-nilai yang lebih tinggi pada bulan Februari, April, Mei, Juni, dan September (Gambar 6). Dalam Gambar 6 juga terlihat, bahwa nilai GI rata-rata pada tahun 2003-2004 berfluktuasi antara 10,2 pada bulan Juli 2004 sampai 67,6 pada bulan April 2004. Nilai GI rata-rata turun terutama pada bulan Juli dan Oktober 2003 serta pada bulan Januari dan Maret 2004, serta pada bulan Mei, Juli, Oktober sampai dengan Desember 2004, yang diduga pada bulan-bulan tersebut terjadi pemijahan.

Didasarkan pada turunnya nilai-nilai GI rata-rata ikan banyar betina pada tiap bulan (Gambar 6), diduga pemijahan ikan banyar terjadi pada bulan Mei sampai dengan Juli dan bulan Oktober (musim peralihan I, timur sampai peralihan II) dengan puncak pada bulan Oktober, dan antara bulan DesemberMaret (musim barat).

\section{Contoh Telur Ikan Banyar}

Dari contoh beberapa gonad ikan banyar TKG V (memijah) pada bulan Juli 2004 telah diperoleh sisasisa telur yang transparan (Gambar 7).

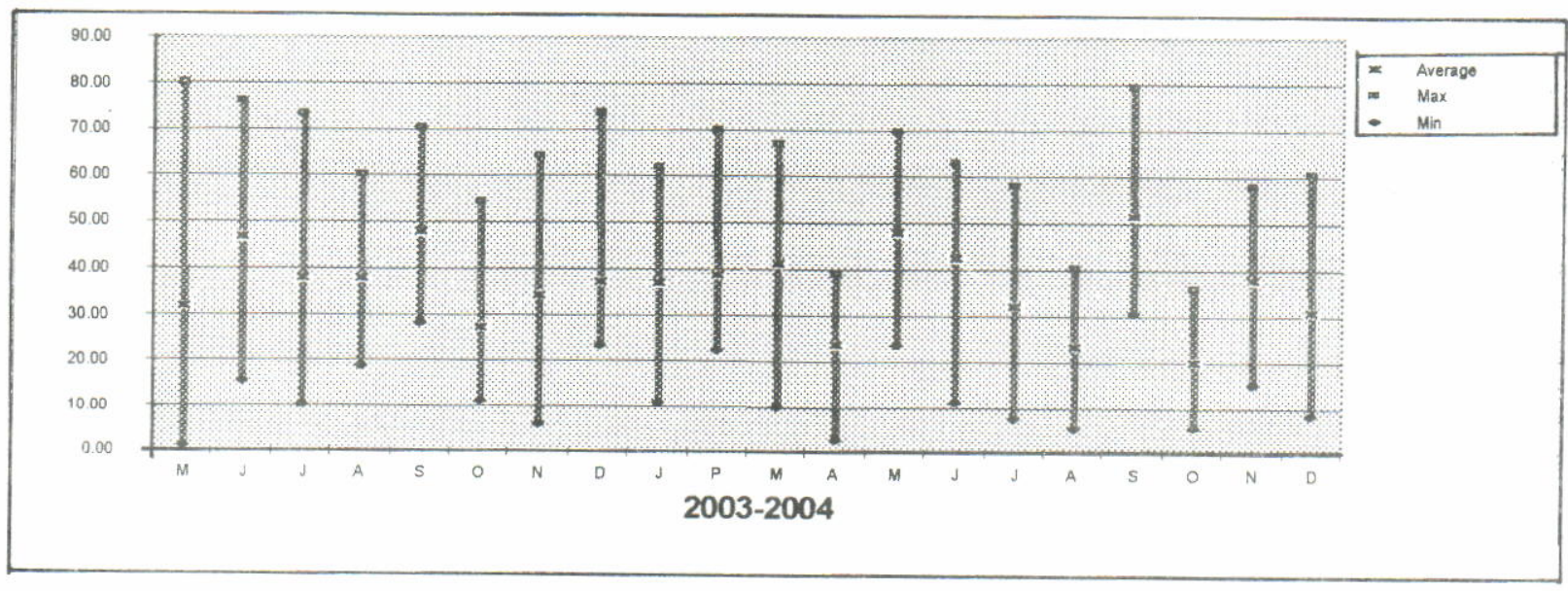

Gambar 5. Figure 5.

Gonad Indeks (GI) ikan layang (Decapterus russelli) dari perairan Selat Malaka. Gonad index of scad (Decapterus russelli) from the Malacca Straits. 


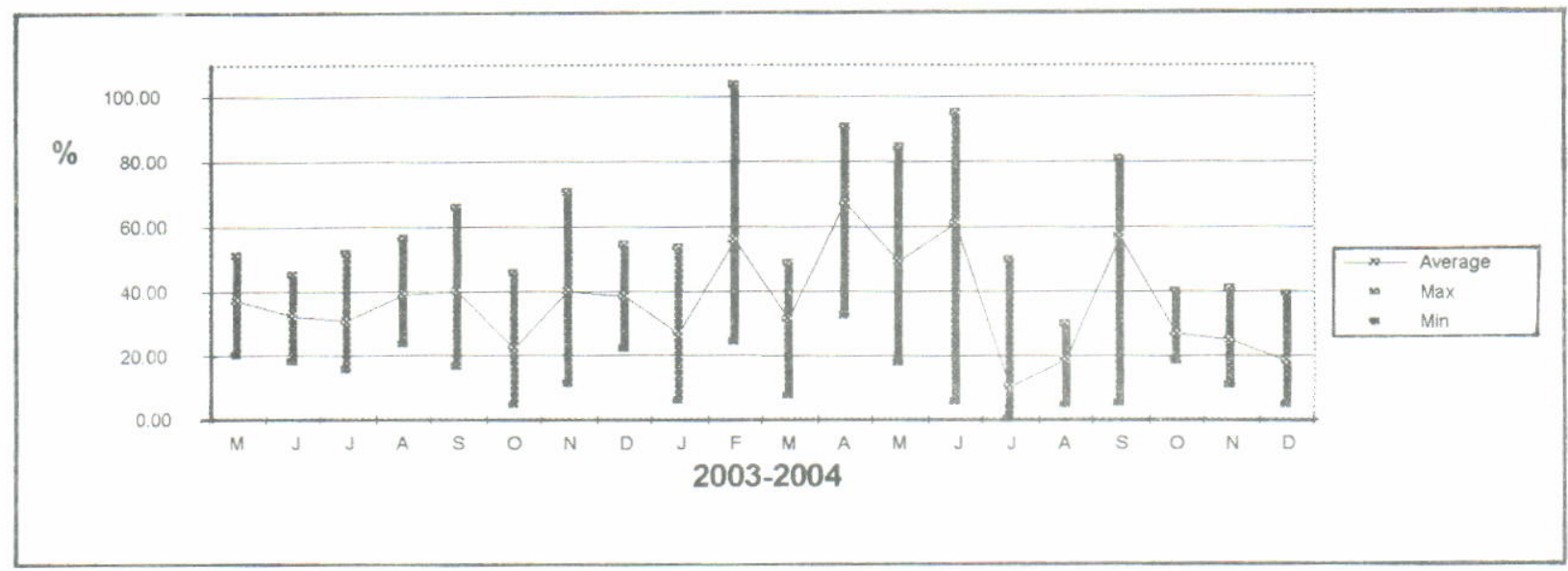

Gambar 6. Figure 6.
Gonad Indeks ikan banyar (Rastrelliger kanagurata) dari perairan Selat Malaka. Gonad index of Indian mackerel (Rastrelliger kanagurata) from the Malacca Straits.

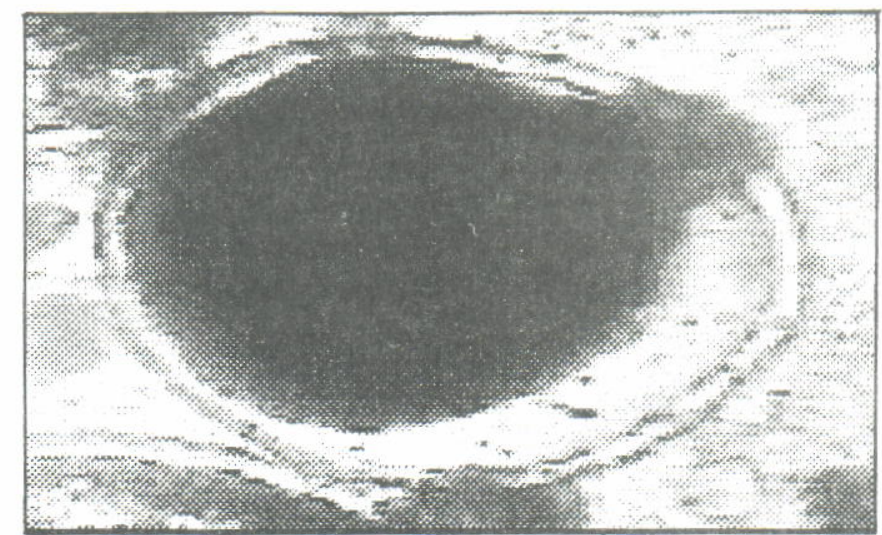

Gambar 7. Telur ikan banyar yang translucent dari contoh gonad TKG V (partially spent) dari perairan Selat Malaka.

Figure 7. Translucent egg from a gonad sample of the-fifth maturity stage (partially spent) of indian mackerel from the Malacca Straits.

Menurut hasil penelitian Rao (1967) diameter telur ikan banyar yang telah mencapai fully development berukuran 570-810 mikron, sedangkan diameter telur yang diperoleh (Gambar 7) berukuran 515-560 mikron. Diduga telur yang berukuran fully development sudah dikeluarkan, yang tinggal adalah telur yang tersisa. Rao (1967) menemukan kelompok ikan banyar yang seiesai memijah (almost spent and spent, TKG V) tertangkap di perairan dekat pantai sebulan setelah musim pemijahan. Kemudian Rao (1967) berasumsi bahwa lokasi pemijahan tidak terlalu jauh letaknya dari daerah penangkapan.

\section{Dugaan Area Pemijahan}

Contoh ukuran ikan banyar yang dikumpulkan Tampubolon (1988) pada tiap bulan dari hasil tangkapan pukat cincin Selat Malaka di perairan lepas pantai timur Sumatera Utara tahun 1985 memperlihatkan modus yang hampir seragam, yaitu medium size. Maka Tampubolon (1988) menduga, dari daerah penangkapan tersebut tertangkap populasi ikan banyar yang sedang bermigrasi ke area pemijahan, walaupun area pemijahan ikan banyar di Selat Malaka belum diketahui.

Diduga di perairan Selat Malaka, area pemijahan ikan banyar dan layang terletak di bagian utara karena di bagian ini terdapat isodepth 200 meter (ujung paparan Sunda) kemudian slope laut dalam (Laut Andaman) (Gambar 8).

Di Selat Malaka bagian selatan yaitu perairan sebelah timur Propinsi Riau, kemungkinan adanya daerah pemijahan ikan banyar sangat kecil mengingat bagian perairan ini relatif dangkal dan sempit, serta berkadar garam yang relatif rendah $(<30 \%)$ dibandingkan dengan di bagian utara. Untuk membuktikan lokasi yang pasti dari daerah pemijahan tersebut harus dilakukan penelitian oseanografis mencakup fisik (arus) dan biologi (plankton, telur, dan larva ikan). Tidak tertutup kemungkinan bahwa daerah pemijahan beberapa jenis ikan pelagis kecil di perairan Selat Malaka 


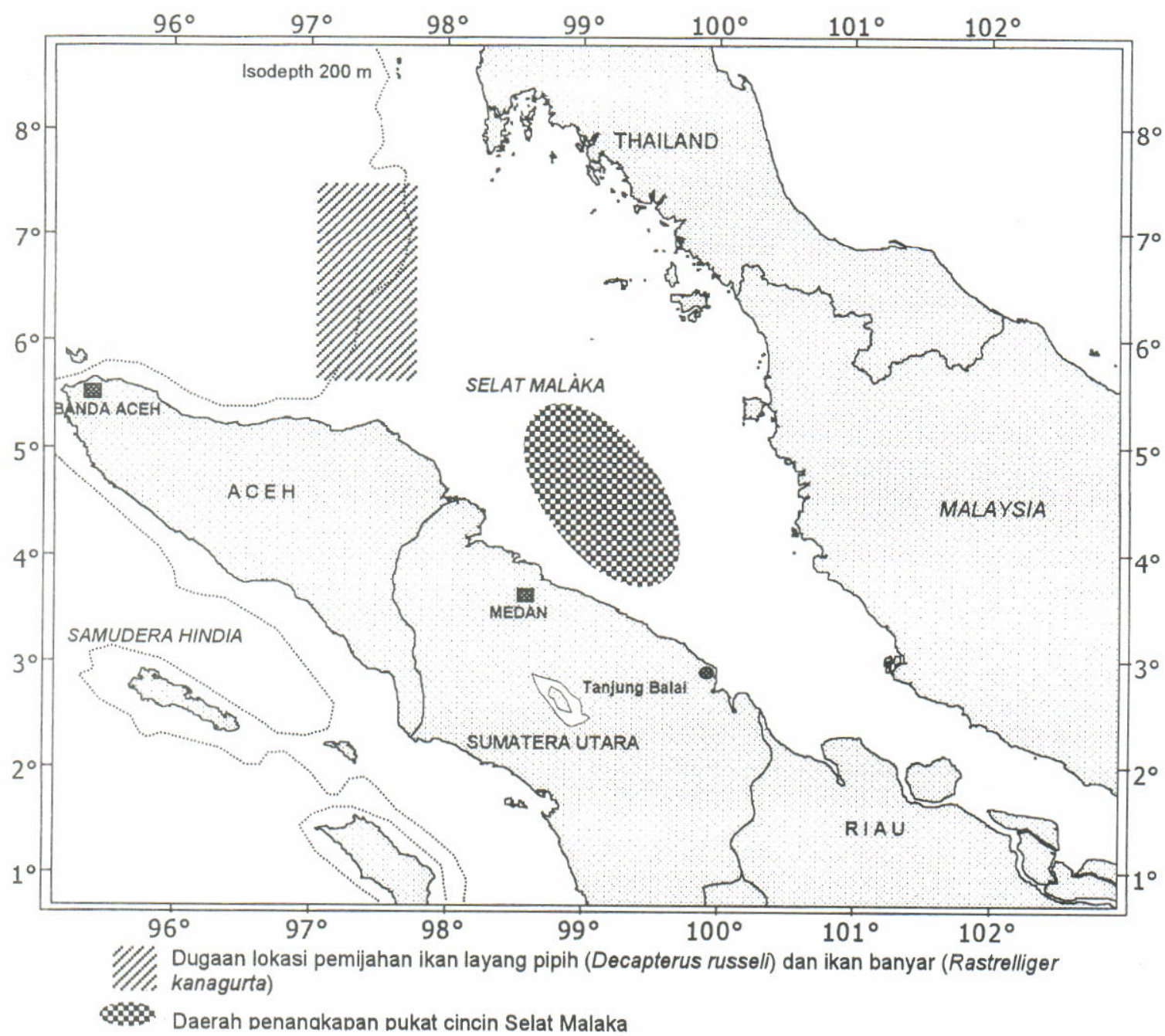

Gambar 8. Dugaan lokasi pemijahan ikan pelagis kecil dan daerah penangkapan pukat cincin di perairan

Figure 8. Predieted spawning location of small pelagic fishes and fishing ground of purse seine in Malacca Straits.

berada di luar wilayah Indonesia. Sutthakorn \& Saranakomkul (1987) telah menemukan lokasi daerah pemijahan ikan kembung perempuan (Rastrelliger brachyosoma) menurut penelitian bioreproduksi dan survei telur dan larva di perairan Selat Malaka bagian utara yang termasuk wilayah Thailand (Area II). Lokasi pemijahan tersebut berada di sekitar garis isodepth $200 \mathrm{~m}$.

\section{KESIMPULAN}

1. Jumlah ikan betina dan jantan pada contoh ikan layang di perairan Selat Malaka masih seimbang, sedangkan pada contoh ikan banyar jumlah ikan jantan cenderung lebih besar. Perbandingan betina: jantan untuk ikan layang 1,00:0,93 dan untuk ikan banyar 1,00:1,17.

2. Jenis ikan betina dari ikan layang dan banyar didominasi oleh ikan yang matang gonad (TKG III atau mulai matang gonad dan TKG IV atau matang gonad).
3. Musim pemijahan di perairan Selat Malaka untuk ikan layang berlangsung pada bulan April sampai dengan Oktober dengan puncak pada bulan Oktober, untuk ikan banyar dari bulan Mei sampai dengan Oktober dan dari bulan Desember sampai dengan Pebruari, dengan puncak pada bulan Juli dan Oktober.

4. Lokasi pemijahan ikan layang dan banyar diduga terletak di bagian utara selat, sekitar garis isodepth $200 \mathrm{~m}$.

5. Nilai dugaan panjang pertama kali matang gonad $\left(\mathrm{I}_{\mathrm{m}}\right)$ ikan layang $16 \mathrm{~cm}$ FL dan ikan banyar $17 \mathrm{~cm}$ FL. Nilai-nilai Lm tersebut masih sama dengan yang diperoleh pada periode tahun 1995-1997.

\section{DAFTAR PUSTAKA}

Anonimus. 1998. Penelitian pengusahaan sumber daya perikanan pelagis kecil di perairan ZEE Selat 
Malaka tahun anggaran 1997/1998. Laporan Teknis Kegiatan. Balai Penelitian Perikanan Laut Jakarta: 16 hal.

Atmaja, S. B., B. Sadhotomo, \& Suwarso. 1995. Reproduction of the main small pelgic species in Biology, dynamics, exploitation of the small pelagic fishes in the Java Sea. Editors: M. Potier \& S. Nurhakim. AARD, Ministry of Agriculture of Indonesia, ORSTOM, European Union Jakarta. P: 68-84.

Bal, D. V., \& K. V. Rao. 1984. Marine fisheries. Part 1: Methodology in fisheries biology. Tata M.G. Hill Com. Ltd. New Delhi: p.1-24.

Batts, B. S. 1972. Sexual maturity, fecundity, and sex ratio of skipjack tuna (K. pelamis Linn.) in North Carolina Waters. Trans. Amer. Fish. Soc. 101 (4)1972: 626-637

Chee Phaik Ean. 2000. The status of the rastrelliger (kembung) fishery on the West Coast of Peninsula Malaysia in Fishcode management. Suplement to The Report of A Workshop on The Fishery and Management of Short Mackarel (Rastrelliger spp.) on The West Coast of Peninsulas Malaysia. FAO of The UN. Rome: 1-20.

Hariati,T., Suwarso, \& Wudianto. 2004. Biologi ikan pelagis kecil di perairan Laut Cina Selatan yang didaratkan di Pelabuhan Perikanan Nusantara Pemangkat, Kalimantan Barat. Disampaikan dalam: 'Workshop Sumber Daya Ikan' di Pemangkat, Kalimantan Barat, 25 November 2004: 14 hal.

Holden, M. J., \& D. F. S. Raitt. 1974. Manual of fisheries science. Part 2: Methods of recources investigation and their application. FAO Fish. Tech. Pap. (115): 214 p.

Nurhayati. 2002. Karakteristik hidrografi dan arus di perairan Selat Malaka dalam Perairan Indonesia.
Oseanografi Biologi dan Lingkungan Pusat Penelitian Oseanografi Lembaga IImu Pengetahuan Indonesia. Jakarta: 1-8.

Rao,V. R. 1967. Spawning behavior and fecundity of the indian mackerel, Rastrelliger kanagurta (CUVIER) at Mangalore. Indian Journal of Fisheries Vol.14 (No.182): p.171-186.

Shuttakorn, P. \& R. Saramakomkul. 1987. Biological aspects of chub mackarels and round scads in Investigations on the mackarel and scad resources of the Malacca Straits. Annexure 2. Bay of Bengal Programme. FAO of The UN. Colombo P: 48-80.

Tampubolon, G. 1988. Growth and mortality estimation of indian mackarel (Rastrelliger kanagurta) in the Malacca Strait, Indonesia. Contribution to Tropical Fisheries Biology: Papers by the Participants of FAO/DANIDA Follow up Training Cources. Edited by S. Venema, J Moller Christensen and D. Pauly. FAO Fisheries Report 389, Rome: p. 372-384.

Tampubolon, G \& Merta, I. G. S. 1986. Mackarel fisheries in the Malacca Straits in Investigations on the mackarel and scad resources of the Malacca Straits bay of bengal programme. Annexure 4 FAO of The UN. Colombo, P: 101-116.

Udupa, K. S. 1986. Statistical method of estimating the size of first maturing in fishes. Fishbyte 4 (2): 8-10.

\section{UCAPAN TERIMA KASIH}

Terima kasih yang tak terhingga disampaikan kepada Yth. Ir. Endang Lubis (Mantan Kepala Dinas Pertanian sampai tahun 2004) serta Ir. Eddy Surya, Sdr. Rizeidsyah, Sdr. Sangkot P., dan Sdr. Erwin di Dinas Perikanan dan Kelautan Kota Tanjung Balai atas bantuan dan kerja sama yang telah diberikan pada saat berlangsungnya penelitian ini pada periode bulan Mei 2003 sampai dengan April 2005. 